\title{
Genetically Modified Animal Models for Lipoprotein Research
}

\author{
Masashi Shiomi, Tomonari Koike \\ and Tatsuro Ishida \\ Additional information is available at the end of the chapter
}

http://dx.doi.org/10.5772/50258

\section{Introduction}

Coronary artery disease (CAD) is a leading cause of death in the world and one of the major risk factors for $\mathrm{CAD}$ is dyslipidemia. In understanding dyslipidemia and developing therapeutics, animal models, especially genetically modified animals, have played important roles and contributed greatly to progress in this field. Before the development of genetically modified animals, the Watanabe heritable hyperlipidemic (WHHL) rabbit, the first animal model for familial hypercholesterolemia, developed by Yoshio Watanabe in 1980 (Watanabe, 1980), helped to verify a low-density lipoprotein (LDL) receptor-pathway in vivo and to clarify lipoprotein metabolism in humans (Goldstein, 1983), in addition to the process by which atherosclerosis develops (Shiomi, 2009). Furthermore, WHHL rabbits have contributed to the development of hypocholesterolemic agents, statins, (Watanabe, 1981; Tsujita, 1986) and to clarifying anti-atherosclerotic effects (Watanabe, 1988; Shiomi, 1995; 2009). In the present, WHHL rabbits were improved by selective breeding to produce the WHHLMI strain, which suffers from severe and vulnerable coronary atheromatous plaques and myocardial infarction due to coronary occlusion with progression of atherosclerotic plaques (Shiomi, 2003). However, WHHL or WHHLMI rabbits were not suitable for studying the role of genes in lipid metabolism, because it is difficult to apply genetic modification techniques to rabbits.

The first transgenic mice were developed in 1982 (Gordon, 1982) and the first knockout mice in 1984 (Bradley, 1984). Genetically modified mice are commonly used to study lipoprotein metabolism and atherosclerosis. The first transgenic mice for lipoprotein metabolism were LDLR-overexpressing mice, developed in 1988 (Hofmann, 1988), and the 
first knockout (KO) mice for lipoprotein metabolism were apolipoprotein (apo) E-KO mice, developed in 1992 (Zhang, 1992). Thereafter, numerous genetically modified mouse models were produced and these mice have contributed to a better understanding of lipoprotein metabolism. However, we should recognize that the lipoprotein metabolism of genetically modified mice is not entirely the same as that of humans, despite hyperlipidemia or hypercholesterolemia. In addition, recent studies have demonstrated different phenotypes manifested in mice and rabbits after the same gene transfer (Fan, 2003). The first transgenic rabbit was developed in 1985 (Hammer, 1985) and the first transgenic rabbit for lipoprotein metabolism, the hepatic lipase-overexpressing rabbit, was developed in 1994 (Fan, 1994). The differences in phenotype following gene transfer between mice and rabbits may be due to species differences in lipoprotein metabolism. When using animal models in experimental research, one has to be careful interpreting the results. Since other chapters explain in detail the functions of enzymes, apolipoproteins, and receptors relating to lipoprotein metabolism, this chapter concentrates on introducing various genetically modified animals and species differences in phenotype expression after gene modification for researchers wishing to study lipoprotein metabolism.

\section{Species differences in lipoprotein metabolism}

\subsection{Species differences in lipoprotein profiles}

Fig. 1 shows lipoprotein profiles of mice, rabbits, and humans analysed with high performance liquid chromatography (HPLC). The main lipoprotein is LDL in human normal subjects but high-density lipoprotein (HDL) in wild-type mice. LDL is increased markedly in the plasma of patients with hypercholesterolemia (Yin, 2012) and WHHLMI rabbits, but lipoproteins that elute at the position of very low-density lipoprotein (VLDL) are increased in apoE-deficient mice, one of the most commonly used genetically modified mice (Piedrahita, 1992). Although serum lipid levels and the lipoprotein profile of apoE$\mathrm{KO}$ mice vary depending on the colony, the lipoprotein profile of apoE-KO mice is similar to that of cholesterol-fed rabbits (Yin, 2012). In LDL receptor (LDLR)-deficient individuals, LDL increased markedly in patients (familial hypercholesterolemia) and rabbits (WHHLMI rabbits) despite a normal diet or chow, while plasma LDL levels were not so high in homozygous LDLR-KO mice fed standard chow as described by Ishibashi et al. (1993), although serum lipid levels and lipoprotein profiles of LDLR-KO mice vary in each colony similar to those of apoE-KO mice. After consumption of a cholesterolenriched diet, plasma cholesterol levels increased markedly in LDLR-KO mice, similar to FH patients and WHHL rabbits, but the increased lipoprotein fraction eluted at the position of VLDL (Ishibashi, 1994) and the lipoprotein profile was similar to that of cholesterol-fed rabbits (Yin, 2012). These differences in lipoprotein profiles between mice and humans or rabbits are probably due to the species differences in lipoprotein metabolism. 

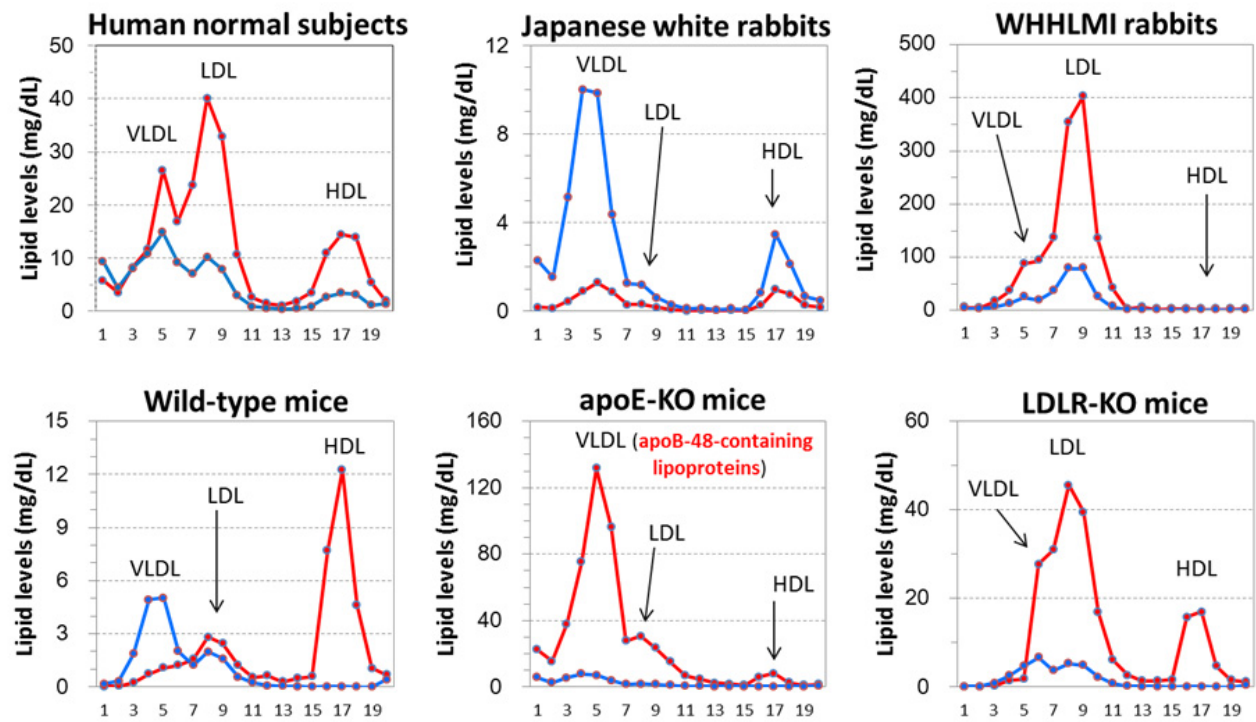

Figure 1. Lipoprotein profiles of a healthy human, rabbits, and mice. Lipoprotein profiles were analyzed with high performance liquid chromatography. Animals were fed standard chow. Red lines indicate cholesterol and blue lines indicate triglyceride

\subsection{Lipoprotein metabolism in mice and rats}

Fig. 2 shows a schematic diagram of lipoprotein metabolism in wild-type mice and rats. Dietary cholesterol is absorbed at the intestine mediated by Niemann-Pick C1-like 1 protein (NPC1L1) (Altmann, 2004) and ATP-binding cassette transporters (ABC) (Berge, 2000). Dietary fat is hydrolyzed to form monoglycerides and fatty acids in the intestine. These lipolytic products are translocated to the enterocyte membrane, and migrate to the endoplasmic reticulum. Overexpression of the tis7 gene in mice increases triglyceride absorption (Wang, 2009), and the transport of saturated fatty acids and cholesterol is decreased in fatty acid-binding protein (FABP)-KO mice (Newberry, 2009). Monoglycerides and fatty acids are re-esterified into triglycerides at the cytoplasmic surface of the endoplasmic reticulum. Synthesized triglycerides, cholesterol, and apolipoproteins are assembled in chylomicron particles. In the process of chylomicron assembly, MTP assists in binding lipids to apolipoproteins (Hussain, 2012). Since the apoB mRNA editing enzyme (apobec-1) functions at the intestinal wall, chylomicron particles contain apoB-48 as a major apolipoprotein but do not contain apoB-100. Chylomicron particles are released into the lacteal vessel. ApoB-48 is a marker of exogenous lipoprotein 
in humans and rabbits. At the capillary of peripheral tissue, chylomicron particles release free fatty acids (FFA) to adipose tissues mediated by lipoprotein lipase (LPL) and are converted to chylomicron remnants (Goldstein, 1983). Chylomicron remnants rapidly disappear from the circulation through apoE-receptors (apoER, remnant receptors) expressed in the liver. The metabolism of exogenous lipoproteins is preserved across species. In endogenous lipoprotein metabolism, cholesterol and other lipids synthesized in the liver are assembled in VLDL particles. Since apobec-1 is not expressed in the liver in humans and rabbits, VLDL particles contain apoB-100 but not apoB-48. However, VLDL particles of mice and rats contain both apoB-100 and apoB-48, because apobec- 1 is expressed in the liver (Greeve, 1993). At the capillary in peripheral tissue, VLDL particles release FFA similar to chylomicron particles, which is then transformed into intermediatedensity lipoprotein (IDL) (Goldstein, 1983). Part of the remaining VLDL particles and/or partially catalyzed VLDL particles bind to VLDL receptors expressed in peripheral tissue (Takahashi, 2004). Finally, apoB-48-containing VLDL and IDL in mice and rats disappear from the circulation through apoER expressed in the liver similar to chylomicron remnants. Some IDL particles containing apoB-100 bind to LDLRs in the liver, the rest release fatty acids via hepatic lipase (HL) and are transformed into LDL. LDL particles bind to LDLRs expressed at the surface of somatic cells. Therefore, a marker of endogenous lipoproteins is apoB-100 in humans and rabbits but endogenous lipoproteins of mice and rats contain both apoB-100 and apoB-48. Since the fractional catabolic rate for apoB-48-containing lipoproteins is very high compared to that for apoB-100-containing lipoproteins (Li, 1996), concentrations of VLDL and LDL are very low in wild-type mice and rats compared to humans. In reverse cholesterol transport from peripheral tissue to the liver, high-density lipoproteins (HDLs) receive free cholesterol from macrophages through scavenger receptor type B-I (SR-BI) and ABCs such as ABCA1 (Rohrer, 2009). The free cholesterol transported from macrophages is esterified by lecithin:cholesterol acyltransferase (LCAT) in plasma. The esterified cholesterol in HDL particles is transferred to VLDL, IDL, and LDL in plasma by cholesterol ester transfer protein (CETP) in humans and rabbits (Son, 1986), while mice and rats do not have CETP activity in plasma (Agellon, 1991). Therefore, the cholesterol ester in HDL particles is not transferred to apoB-containing lipoproteins in mice and rats. This is one of the major reasons why HDL is the predominant lipoprotein in these two species. Circulating HDL particles bind to SR-BI in the liver. Therefore, the large difference in lipoprotein metabolism between mice / rats and humans / rabbits is characterized by both the expression of apobec- 1 in the liver and absence of CETP in the plasma of mice and rats. Dyslipidemia develops when lipoprotein metabolism is impaired. For example, LDLR deficiency causes familial hypercholesterolemia, and impaired LPL function causes hypertriglyceridemia. A number of animal models including transgenic animals, knockout animals, and spontaneous mutant animals can develop hypercholesterolemia, hypertriglyceridemia, and postprandial hypertriglyceridemia. However, the lipoprotein profile of these mice is greatly different from that of human patients. 


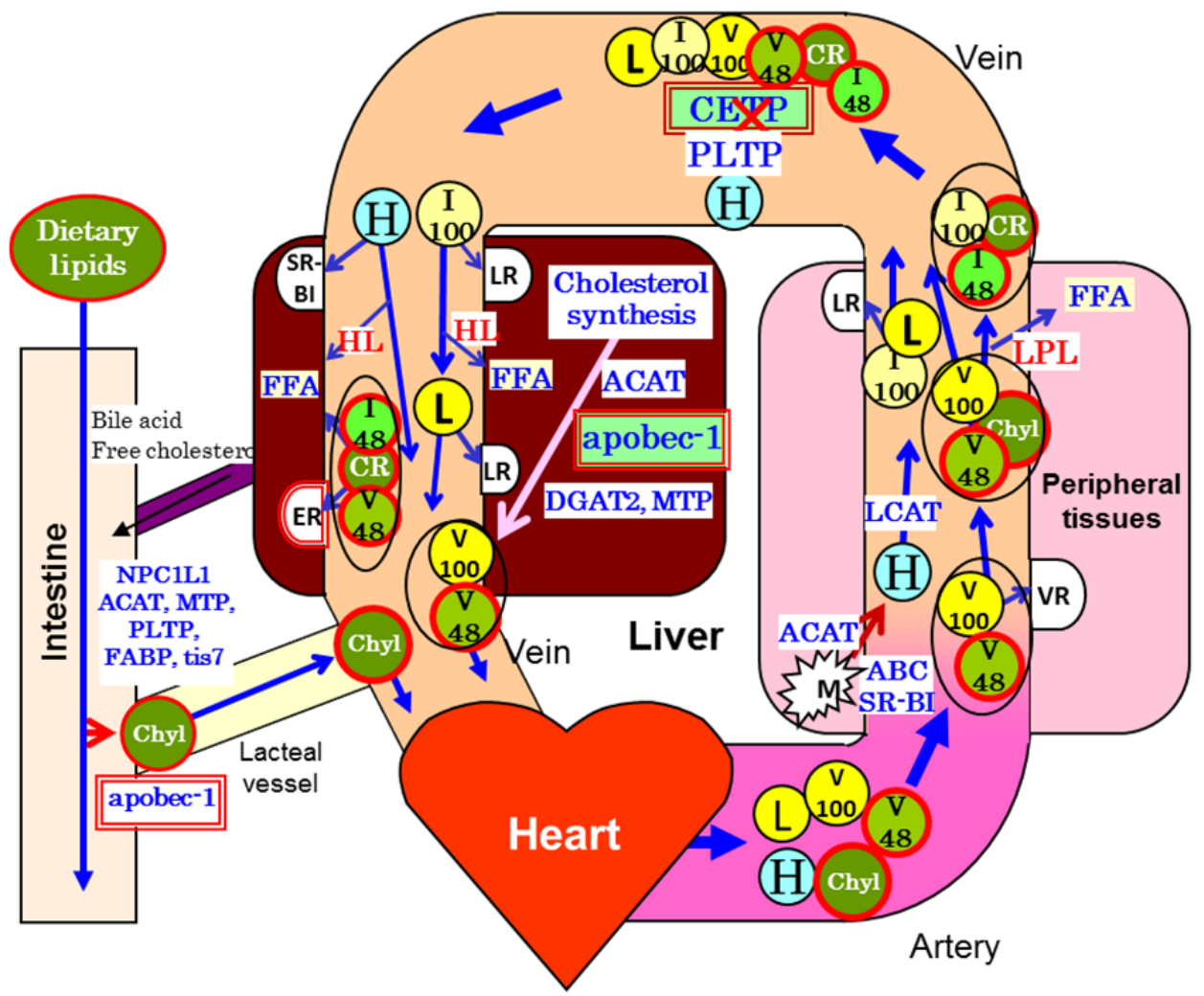

Figure 2. Lipoprotein metabolism in mice and rats (wild-type). Abbreviations: ACAT, acylCoA:cholesterol acyltransferase; apoB, apolipoprotein B; CETP, cholesterol ester transfer protein; Chyl, chylomicron; CR, chylomicron remnant; DGAT2, acyl-Co-A:diacylglycerol acyltransferase 2; ER, apoE receptor; FABP, fatty acids-binding protein; FFA, free fatty acids; $\mathrm{H}$, high-density lipoprotein; HL, hepatic lipase; I48, intermediate-density lipoprotein (IDL) with apoB-48; I100, IDL with apoB-100; L, low-density lipoprotein (LDL); LCAT, lecithin:cholesterol acyltransferase; LPL, lipoprotein lipase; LR, LDL receptor; $M$, macrophage; MTP, microsomal triglyceride transfer protein; NPC1L1, Niemann-Pick C1-like 1; PLTP, phospholipid transfer protein; SR-BI, scavenger receptor type B-I; V48, very lowdensity lipoprotein (VLDL) with apoB-48; V100, VLDL with apoB-100; VR, VLDL receptor

\section{Genetically modified animal models as tools for studying lipoprotein metabolism}

Genetically modified animals for studying lipoprotein metabolism are summarized in Table 1. The list includes genetically modified mice, rats, rabbits, and chicken, but not double- or triple-modified animals. Several double- or triple-modified mice were developed by crossbreeding, for example, the apoE/LDLR-dKO mouse, the apoE/SRBI-dKO mouse, and others. Genetically modified animals can be good tools for clarifying the role of genes in lipoprotein metabolism and atherosclerosis if researchers take into consideration species differences. 


\begin{tabular}{|c|c|c|c|}
\hline & Transgenic animals & \multicolumn{2}{|r|}{ Knockout animals } \\
\hline & mouse $\quad$ rat & rabbit & mouse $\quad$ rat \\
\hline \multicolumn{4}{|c|}{ Apolipoprotein } \\
\hline apoA-I & Walsh, 1989 Swanson, 1992 & Duverger, 1996 & Plump, 1997 \\
\hline apoA-II & Marzal-Casacub, 1996 & Koike, 2009 & Weng, 1996 \\
\hline apoB100 & Farese, 1995 & Fan, 1995 & Young, 1995 \\
\hline apoC-I & Simonet, 1991 & & Gautier, 2002 \\
\hline apoC-II & Shachter, 1994 & & \\
\hline apoC-III & Aalto-Setala, 1992 & & Ding, 2011 \\
\hline apoC-IV & Allan, 1996 & & \\
\hline apoE & Shimano, 1992 & Fan, 1998 & Piedrahita, 1992 \\
\hline apo(a) & Chiesa, 1992 & Rouy, 1998 & \\
\hline apoM & Christoffersen, 2008 & Christoffersen, & 2008 \\
\hline \multicolumn{4}{|c|}{ Cholesterol absorption in intestine } \\
\hline NPC1L1 & & & Altmann, 2004 \\
\hline ABCA1 & & & McNeish, 2003 Mulligan, 2003 \\
\hline ACAT1 & & & Buhman, 2000 \\
\hline Apobec 1 & & & Kendrick, 2001 \\
\hline MTP & & & Xie, 2006 \\
\hline PLTP & & & Liu, 2007 \\
\hline SR-BI & & & Mardones, 2001 \\
\hline FABP & & & Newberry, 2009 \\
\hline tis7 & Wang, 2005 & & \\
\hline \multicolumn{4}{|c|}{ VLDL secretion from liver } \\
\hline DGAT2 & & & Liu, 2008 \\
\hline MTP & & & Raabe, 1998 \\
\hline Apobec-1 & & & Morrison, 1996 \\
\hline \multicolumn{4}{|c|}{ Lipolytic enzyme } \\
\hline LPL & Shimada, 1993 & Fan, 2001 & Coleman, 1995 \\
\hline HL & Braschi, 1998 & Fan, 1994 & Gonzalez-Navarro, 2004 \\
\hline EL & Ishida, 2003; & & Ishida, 2003; Ma, 2003 \\
\hline \multicolumn{4}{|c|}{ Lipoprotein metabolism } \\
\hline LDLR & Hofmann, 1998 & & Ishibashi, 1993 Asahina, 2012 \\
\hline PCSK9 & Herbert, 2010 & & Rashid, 2005 \\
\hline VLDLR & & & Frykman, 1995 \\
\hline SR-type A & & & Suzuki, 1997 \\
\hline \multicolumn{4}{|c|}{ Reverse cholesterol transport } \\
\hline ABCA1 & Vaisman, 2001 & & McNeish, 2000 \\
\hline ABCG1 & Kennedy, 2005 & & Kennedy, 2005 \\
\hline SR-BI & Wang, 1998 & & Rigotti, 1997 \\
\hline LCAT & Vaisman, 1995 & Hoeg, 1996 & \\
\hline CETP & Aggellon, 1991 Herrera, 1999 & & \\
\hline PLTP & Jiang, 1996 & Masson, 2011 & Jiang, 1999 \\
\hline
\end{tabular}

Table 1. List of genetically modified animals regarding lipoprotein metabolism. 


\subsection{Cholesterol absorption in the intestine}

Recent studies using genetically modified animals have help to clarify the mechanism of cholesterol absorption in the jejunum. Dietary cholesterol forms micelles with bail acids in the lumen of the jejunum, which are then transported through NPC1L1. Thereafter, the free cholesterol is esterified by acyl coenzyme A:cholesterol acyltransferase 2 (ACAT2) and chylomicron particles are formed by the packaging of esterified cholesterol, triglyceride, and apolipoprotein B by MTP (Hussain, 2012). NPC1L1 was found by Altman et al (2002). NPC1L1, highly expressed in the jejunum and located on the surface of absorptive enterocytes, is critical for the intestinal absorption of dietary and biliary cholesterol (Altmann, 2004). NPC1L1 mediates cholesterol uptake through vesicular endocytosis. Davis et al (2004) produced NPC1L1 KO mice, which had substantially reduced intestinal uptake of cholesterol and sitosterol. NPC1L1-deficiency resulted in the up-regulation of intestinal hydroxymethylglutaryl-CoA synthase mRNA expression and an increase in intestinal cholesterol synthesis, the down-regulation of ABCA1 mRNA expression, and no change in ABCG5 and ABCG8 mRNA levels. Therefore, NPC1L1 is required for intestinal uptake of both cholesterol and phytosterols and plays a major role in cholesterol homeostasis. These findings in NPC1L1-KO mice were similar to results obtained with an inhibitor of cholesterol absorption, ezetimibe (Garcia-Calvo, 2005). Phospholipid transfer protein (PLTP) is also involved in cholesterol absorption in the intestine (Liu R, 2007). PLTP-KO mice absorb significantly less cholesterol than wild-type mice. In addition, mRNA levels of NPC1L1 and ABCA1 and MTP activity levels were significantly decreased in the small intestine of PLTP-KO mice. The free cholesterol taken up through NPC1L1 and PLTP is esterified by ACAT2. Experiments with ACAT2-KO mice demonstrated that a deficiency of ACAT2 activity inhibits cholesterol absorption in the intestine (Buhman, 2000). In the intestine, lipids absorbed are packaged with apolipoproteins and form chylomicron particles. The major structural apolipoprotein in chylomicron particles is apoB-48. ApoB-48 is produced by apobec-1, which inserts a stop codon. A deficiency of apobec- 1 in the intestine resulted in reduction in the secretion and assembly of chylomicron particles (Kendrick, 2001). These results from apobec-1$\mathrm{KO}$ mice suggested that apoB-48 is involved in the assembly of chylomicron particles (Lo, 2008). Finally, absorbed lipids and synthesized apolipoproteins are assembled by MTP. MTP$\mathrm{KO}$ mice demonstrated a decrease in cholesterol absorption and chylomicron secretion, in addition to manifestations of steatorrhea (Xie, 2006). Although ABC and SR-BI were considered important to cholesterol absorption until the year 2000, SR-BI is not essential for intestinal cholesterol absorption (Mardones, 2001). Cholesterol absorption was independent of ABCA1 in KO mice (McNeish, 2000) and ABCA1-mutant chickens (Mulligan, 2003). Thus, studies with genetically modified animals have verified the mechanisms of dietary lipid absorption revealed by experiments in vitro.

\subsection{Formation and secretion of VLDL particles from liver}

The liver is the main organ in lipoprotein metabolism. Endogenous lipoprotein (VLDL) particles are produced in liver. The production and secretion of VLDL consist of the 
synthesis of cholesterol, triglyceride, phospholipids, and apolipoproteins, and assembly of these components. As described, apobec-1 is expressed in the liver in mice and rats, but not in humans and rabbits. Therefore, apoB-48-containing VLDL particles are secreted from the mouse and rat liver. Compared to those containing apoB-100, VLDL particles containing apoB-48 are rapidly cleared from circulation through apoER expressed on hepatocytes, similar to chylomicron remnants (Fig 2). To better approximate human lipoprotein metabolism, apobec-1-deficient mice were developed by gene targeting (Morrison, 1996). The LDL levels increased and HDL levels decreased in the circulation. However, overexpression of human apoB-100 showed different results between mice and rabbits. Plasma cholesterol levels decreased in apoB-100-overexpresing mice (Farese, 1996), although plasma cholesterol, triglyceride, and LDL levels increased and HDL levels decreased in apoB-100-overexpressing rabbits (Fan, 1995). This difference may be due to differences in CETP activity in the circulation between mice and rabbits. In addition, suppression of acylCoA: diacylglycerol acyltransferase 2 (DGAT2) expression by antisense treatment decreased VLDL secretion in mice (Liu, 2008). This suggests that suppression of triglyceride synthesis decreases VLDL secretion. Studies using inhibitors of MTP suggested that MTP plays a key role in the production of VLDL particles and inhibition of MTP activity decreases VLDL secretion in WHHL rabbits (Shiomi, 2001). Indeed, MTP+/- mice fed a high-fat diet demonstrated decreased levels of apoB-containing lipoproteins in plasma (Raabe, 1998). Furthermore, hepatocytes synthesize and/or secrete a lot of apolipoproteins, such as apoA, apoB, apoC, apoE, apoM, and apo(a). The function of these apolipoproteins has been clarified using genetically modified animals. However, influences of the overexpression of apoB, apoE, and apo(a) differ between mice and rabbits. ApoE overexpression resulted in a marked decrease in non-HDL cholesterol in mice (Shimano, 1992), while in rabbits, cholesterol of LDL and HDL increased and the fractional catabolic rate of chylomicron also increased (Fan, 1998). These differences between mice and rabbits may be due to CETP activity and the expression of abobec- 1 in mouse liver. Lipoprotein (a), an atherogenic lipoprotein, is formed by the binding of apo(a) to LDL particles and is detected in plasma of only humans and monkeys. In human-apo(a) transgenic mice (Chiesa, 1992), apo(a) does not bind to mouse LDL particles, while human apo(a) binds to rabbit LDL particles and lipoprotein (a) is also atherogenic in rabbits (Rouy, 1998; Fan, 1999). Therefore, the role of endogenous apoB-containing lipoproteins (VLDL, IDL, and LDL) in the regulation of plasma lipid levels differs between genetically modified mice and rabbits or humans.

\subsection{Lipolysis of apoB-containing lipoproteins}

Lipoproteins are transporters in circulation that provide cholesterol as a material for steroid hormones and the cytoskeleton, and triglycerides (fatty acids) for energy to peripheral tissue. In the transportation of fatty acids, lipoprotein lipase (LPL), hepatic lipase (HL), and endothelial lipase (EL) function at capillaries and apoC affects lipolytic activities. LPL mediates the lipolysis of VLDL and chylomicrons, and these lipoprotein particles are transformed into IDL and chylomicron remnants, respectively. Although LPL-/- mice die 
within a day after birth because of dramatic hypertriglyceridemia, impaired fat tolerance, and hypoglycemia (Weinstock, 1995), these LPL-KO mice could be rescued by transient LPL expression induced by adenoviral-mediated gene transfer (Strauss, 2001). Rescued adult LPL-KO mice exhibit severe hypertriglyceridemia as patients with homozygous LPLdeficiency. LPL+/- mice showed increases in plasma triglyceride levels due to increases in the fraction of VLDL and chylomicrons in the circulation. Overexpression of LPL in mice (Shimada, 1993) and rabbits (Fan, 2001) caused decreases in plasma triglyceride, VLDL, and LDL levels, in addition to the suppression of atherosclerotic lesions (Shimada, 1996). ApoC-I modulates this metabolism. Although knockout of apoC-I gene did not affect serum lipid levels, expression of human CETP markedly increased levels of cholesterol ester in plasma, VLDL, and LDL in apoC-I-KO mice (Gautier, 2002). In contrast, in transgenic mice overexpressing human apoC-I, plasma triglyceride and total cholesterol levels were increased compared to those in wild-type mice. In addition, overexpression of apoC-I, apoCII, apoC-III, and apoC-IV also increased plasma triglyceride and total cholesterol levels, and suppressed LPL activity in mice (Simonet, 1991; Shachter, 1994; Aalto-Setala, 1992; Allan, 1996) and rabbits (Ding, 2011). HL modulates the metabolism of both apoB-containing and apoA-containing lipoproteins. In apoE-KO mice, deficiency of HL showed a decrease in the fractional catabolic rate of apoB-48-containing VLDL, IDL and LDL despite no effects on apoB-100-containing LDL, in addition to increases in total cholesterol and triglyceride levels in apoB-containing and apoA-containing lipoproteins (Mezdour, 1997 \& Gonzalez-Navarro $\mathrm{H}, 2004)$. However, development of atherosclerotic lesions was reduced in HL-KO mice. In HL-transgenic mice (Brashci, 1998) and rabbits (Fan, 1994), catabolism of both HDL and apoB-48-containing lipoproteins is enhanced, and plasma total cholesterol and triglyceride levels are decreased. Therefore, HL may be associated with catabolism of not only apoBcontaining lipoproteins but HDL. EL is located in arterial endothelial cells and has phospholipase activity against phospholipids in HDL particles (Broedl, 2003; Ishida, 2003). EL hydrolyzes phospholipids on HDL particles and promotes catabolism of HDL. Overexpression of EL decreases in HDL cholesterol and apoA-I levels decreased in mice (Ishida, 2003; Jaye, 1999). By contrast, a deficiency of EL increases HDL levels (Ishida, 2003; $\mathrm{Ma}, 2003)$, in addition to atherogenic action (Ishida, 2004) and allergic asthma (Otera, 2009). Another study confirmed the high HDL-C levels in EL-/- mice but did not document an association with atherosclerosis (Ko, 2005). Thus, the role of EL in reverse cholesterol transport and atherosclerosis has not been fully elucidated. Further studies are required to clarify the function of EL in the metabolism of HDL and atherosclerosis. In studies about lipolysis, genetically modified animals have demonstrated no species differences, and are useful in this field.

\subsection{Receptor-mediated catabolism of apoB-containing lipoproteins}

\subsubsection{LDL receptor}

Lipoprotein receptors, such as LDLRs, VLDL receptors (VLDLRs), apoE receptors (remnant receptors, apoERs), and scavenger receptors (SRs), take up lipoprotein particles into 
parenchymal cells and/or phagocytes. LDLRs are expressed on the surface of parenchymal cells and bind to circulating LDL. The ligands are apoB-100 and apoE. A deficiency or the suppression of LDLRs results in the accumulation of LDL in the circulation, a condition known as human familial hypercholesterolemia. Several animal models for LDLR-deficiency have been developed. One of the better known models is the WHHL (Watanabe, 1980) or WHHLMI (Shiomi, 2003; 2009) rabbit. WHHL or WHHLMI rabbits show hypercholesterolemia due to LDLR deficiency even when fed standard chow. However, LDLR-KO mice (Ishibashi, 1993 \& 1994) and LDLR-KO rats (Asahina, 2012) showed mildly increased serum cholesterol levels. Sanan et al. (1998) reported that LDLR-KO mice expressing human apoB-100 showed hypercholesterolemia due to the accumulation of LDL in the plasma even in chow feeding. In addition, Teng et al (1997) demonstrated that adenovirus-mediated gene delivery of apobec- 1 reduced plasma apoB-100 levels, leading to the almost complete elimination of LDL particles and a reduction in LDL cholesterol in LDLR-KO mice. These studies suggests that the absence of any increase in plasma cholesterol levels in LDLR-KO mice is due to the expression of apobec- 1 in the liver and apoB-100-containing LDL is a key player in LDLR deficiency to increased plasma cholesterol levels. Expression of LDLRs on the cell surface is regulated by proprotein convertase subtilisin/kexin type 9 (PCSK9). Recently, Huijgen et al. (2012) reported that plasma levels of PCSK9 were associated with LDL cholesterol levels in patients with familial hypercholesterolemia. In addition, overexpression of PCSK9 induced negative modulation of LDLR expression and decreased plasma LDL clearance, also promoting atherosclerosis (Herbert, 2010). In contrast, knockout of PCSK9 resulted in an increase in the LDL receptor protein (Mbikay, 2010) and a decrease in plasma cholesterol levels (Rashid, 2005). Furthermore, PCSK9 regulates the expression of not only LDLRs but VLDLRs and apoERs (Poirier, 2008). Therefore, PCSK9 can be considered a new target in the treatment of hypercholesterolemia.

\subsubsection{VLDL receptor}

VLDL particles are incorporated through VLDLRs. VLDLRs are expressed in heart, muscle, adipose tissues, and macrophages but not in liver in humans and rabbits. In mice, however, VLDLRs are not expressed in macrophages (Takahashi, 2011), suggesting the process of atherogenesis to be somewhat different between mice and humans or rabbits. Knockout of VLDLRs does not affect lipoprotein metabolism but decreases body weight, BMI, and epididymal fat in mice (Frykman, 1995). In addition, LPL activity is decreased by VLDLRdeficiency. These observations suggest VLDLRs to be associated with metabolic syndrome. Furthermore, a recent study suggests that the expression of VLDLRs is affected by PCSK9 (Roubtsova, 2011). Surprisingly, adipose tissues of apoE-KO mice did not express LDLR, VLDLR, and LDLR-related proteins (Huang, 2009), although wild-type mice developed these receptors in adipose tissue. Since the VLDLR has various functions, genetically modified animals may contribute to further studies. 


\subsubsection{Remnant receptor}

Remnant receptors are mainly expressed in liver and contribute to the metabolism of exogenous lipoproteins, which contain apoB-48, in humans and rabbits. Therefore, downregulation of remnant receptor function causes the accumulation of chylomicron remnants in plasma. As their ligand is apolipoprotein E, remnant receptors are also called apoE receptors (apoERs). In mice and rats, VLDL, IDL, and LDL contain apoB-48 due to the expression of apobec- 1 in the liver. These apoB-48-containing lipoproteins bind to apoERs through interaction with the apoE ligand and disappear from the circulation rapidly. The fractional catabolic rate for apoB-48-containing VLDL is remarkably high compared to that for apoB-100-containing VLDL (Gonzalez-Navarro, 2004). This is one of the reasons why concentrations of VLDL and LDL are very low in plasma of mice and rats. In contrast, apoEKO mice have very high VLDL concentration and the VLDL fraction consists of apoB-48 (Gonzalez-Navarro, 2004). Since apoE is a ligand of apoER, lipoproteins containing only apoB-48 cannot bind to apoERs in apoE-KO mice. This is the reason for the hypercholesterolemia in apoE-KO mice. Consequently, the hypercholesterolemia of apoE$\mathrm{KO}$ mice due to the accumulation of apoB-48-containing lipoproteins is different from human hypercholesterolemia due to the accumulation of apoB-100-containing lipoproteins. This difference affects the development of hypocholesterolemic agents.

\subsubsection{Scavenger receptor type A}

Scavenger receptor type A (SR-A) is expressed on phagocytes and plays an important role in the removal of modified lipoproteins, such as oxidized-LDL, acetyl-LDL, and glycated-LDL. Therefore, SR-A plays an important role in atherogenesis. Knockout of SR-A decreases the uptake of modified LDL, but does not affect plasma lipid levels (Suzuki, 1997).

\subsection{Reverse cholesterol transport}

The plasma concentration of HDL is inversely related to the risk of atherosclerotic vascular diseases. HDL plays a key role in the reverse transport of cholesterol from peripheral tissue to liver. Recent studies suggest that HDL is also associated with anti-inflammation, antithrombosis, anti-oxidation, and the enhancement of endothelial function. Newly synthesized apoA-I binds to ABCs (particularly ABC-A1) or SR-BI of macrophages and takes up free cholesterol from macrophages. The complex of apoA-I and free cholesterol is transformed into discoidal nascent HDL (pre- $\beta$ HDL). These nascent HDLs become HDL particles (HDL3) after esterification of the free cholesterol by LCAT in plasma. In the process of the transformation from discoidal HDL to HDL3, HDL takes up apoE and free cholesterol from macrophages mainly by ABCG1. Therefore, as the HDL matures, its cholesterol content increases. In humans and rabbits, CETP in plasma exchanges the cholesterol ester of HDL particles with triglyceride in apoB-containing lipoproteins. Therefore, peripheral cholesterol is transported by two pathways; an LDLR pathway mediated by CETP function and a SR-BI pathway. However, mice and rats do not have CETP activity in plasma. 
Therefore, the pathway of reverse cholesterol transport is markedly different between mice / rats and humans / rabbits.

\subsubsection{Apolipoproteins of HDL particles}

HDL particles contain apoA, apoC, apoE, and apoM. ApoA, the main structural apolipoprotein of HDL particles, is mainly classified as apoA-I, apoA-II, and apoA-IV. ApoA and apoE play an important role in the efflux of cholesterol from macrophages to discoidal and small HDL, respectively. Recent studies suggested that apoM is related to the anti-oxidative function of HDL (Elsoe, 2012).

ApoA-I is a major structural apolipoprotein of HDL particles. ApoA is synthesized mainly in the liver and intestine, and from HDL particles hydrolyzed by HL. Humans and mice have two types of HDLs. One contains only apoA-I and the other, both apoA-I and apoA-II. However, rabbit HDLs are apoA-I particles (Chapman, 1980 \& Koike, 2009). ApoA-I plays an important role in the reverse transport of cholesterol. Overexpression of apoA-I increases HDL-cholesterol levels in mice (Walsh, 1989), rats (Swanson, 1992), and rabbits (Duverger, 1996). In contrast, knockout of the apoA-I gene in mice decreases cholesterol levels in HDL, VLDL, and whole plasma (Plump, 1997). In addition, apoA-I-deficient HDL is a poor substrate for HL and LCAT. These studies using genetically modified animals indicate that apoA-I plays an important role in cholesterol reverse transport. Another major apolipoprotein of HDL is apoA-II. Overexpression of human apoA-II in mouse liver resulted in a decrease in plasma cholesterol levels due to a decrease in HDL cholesterol but an increase in plasma triglyceride levels (Marzal-Casacub, 1996). In addition, LCAT activity and mouse apoA-II levels in plasma were decreased in human apoA-II transgenic mice. Consequently, the changes in plasma lipid levels in human apoA-II transgenic mice may be due to a reduction in levels of mouse apoA-II. These results suggest species differences in apoA-II. In addition, apoA-II is dimer in human but monomer in mice. Knockout of apoA-II in mice resulted in a decrease in not only HDL-cholesterol but non-HDL cholesterol. In addition, the fractional catabolic rate for apoA-I was increased by a deficiency of apoA-II (Weng, 1996). Furthermore, the deficiency was associated with lower free fatty acid, glucose, and insulin levels, suggesting insulin hypersensitivity, while apoA-II does not relate to insulin sensitivity in humans. Therefore, the function of apoA-II is very confusing in mouse models. Conversely, rabbits overexpressing human apoA-II, which do not have apoA-II, lipid levels in plasma and non-HDL lipoproteins were increased but HDL-cholesterol levels and activities of LPL and HL were decreased (Koike, 2009). Therefore, effects of human apoA-II overexpression may be different between mice and rabbits. To clarify the function of apoA-II, more studies are required.

\subsubsection{Transfer of cholesterol from macrophages to $H D L$}

The start of the reverse cholesterol transport process is the transfer of cholesterol from macrophages to apoA-I, in which ABCs play important roles. Several strains of mice with genetically modified ABCA1 and ABCG1 have been produced. Overexpression of ABCA1 in mice increases cholesterol efflux from macrophages, in addition to increases in levels of 
cholesterol, apoA-I, and apoA-II in HDL (Vaisman, 2001). In contrast, ABCA1-KO mice showed a marked decrease in HDL-cholesterol, LDL-cholesterol, and plasma apoB levels, and an absence of apoA-I in plasma, but an increase in cholesterol absorption and the accumulation of lipid-laden macrophages (McNeish, 2000). Furthermore, in ABCG1-KO mice, cholesterol efflux from macrophages to HDL is decreased (Kennedy, 2005). After its efflux from macrophages to apoA-I and HDL, free cholesterol is esterified by LCAT in the plasma. Overexpression of LCAT in mice increases levels of cholesterol, apoA-I, apoA-II, and apoE in plasma, in addition to HDL cholesterol (Vaisman, 1995). LCAT-overexpressing rabbits showed an increase in HDL-cholesterol on a chow diet but non-HDL cholesterol was not increased on a cholesterol diet (Hoeg, 1996). Therefore, LCAT plays an important role in the esterification of free cholesterol in HDL. Studies using ABCA1-KO mice, ABCG1-KO mice, and ABCA1/ABCG1-dKO mice (Out, 2008) have elucidated how cholesterol is transported from macrophages to HDL. ApoE also promotes reverse cholesterol transport by enhancing the efflux of free cholesterol from peripheral macrophages to maturing HDL particles (Hayek, 1994). The efflux of free cholesterol to apoE-binding HDL is mediated by ABCG1/4 (Matsuura, 2006). The efflux from macrophages to apoE-containing HDL3 (small HDL particles) depends on apoE. HDL-cholesterol levels are markedly low in apoE-KO mice, despite being high HDL in wild-type mice (Zhang, 1992). Therefore, the low HDLcholesterol levels in apoE-KO mice are due to a decrease in the efflux of cholesterol from macrophages to HDL. By contrast, the overexpression of apoE induced a marked decrease in apoB-containing lipoproteins in mice (Shimano, 1992), but human apoE3 overexpression increased cholesterol levels in not only HDL but LDL in rabbits (Fan, 1998). These differences between mice and rabbits are due to the activity of CETP in plasma, since no CETP activity is detected in mice but strong activity is found in rabbits.

\subsubsection{Transfer of lipids from HDL to apoB-containing lipoproteins}

One of the main courses of reverse cholesterol transport depends on CETP in plasma in human and rabbits (Son, 1986). However, mice and rats do not have CETP activity in plasma (Agellon, 1991). Therefore, in mice, the HDL cholesterol level is high but cholesterol levels of apoB-containing lipoproteins are markedly low. Overexpression of human CETP in mice induces a decrease in HDL-cholesterol but no changes in cholesterol levels in VLDL and LDL (Agellon, 1991). Similar findings were made in Dahl rats (Herrera, 1999). One of the reasons for no changes in cholesterol levels of non-HDL fraction is due to a rapid clearance of apoB-48-containing lipoproteins through apoER. These results suggest that CETP transfers cholesterol ester from HDL to apoB-containing lipoproteins. Furthermore, CETP expression led to atherosclerosis in Dahl rats fed a cholesterol diet. Therefore, CETPoverexpression can cause complex responses depending on diet. PLTP is a plasma protein, which transfers phospholipids from apoB-containing lipoproteins to HDL. Knockout of PLTP resulted in a decrease in cholesterol (Jiang, 1999; 2001). In PLTP transgenic mice, PLTP did not affect lipid levels of apoB-containing lipoproteins but increased phospholipid and cholesterol levels in HDL (Jiang, 1996). However, overexpression of PLTP in rabbits increased cholesterol levels in apoB-containing lipoproteins but had no effect on HDL lipids 
in a high-cholesterol deiet feeding (Masson, 2011). These differences in the function of PLTP between mice and rabbits may be due to fundamental differences in lipoprotein metabolism, such as CETP activity in the plasma and apobec- 1 expression in the liver. Therefore, one has to be deliberate in interpreting results from gene modification studies.

\subsubsection{HDL receptors}

HDL particles are incorporated by SR-BI, a HDL receptor, expressed in liver. In humans and rabbits, cholesterol is transferred from peripheral macrophages to liver through two pathways, via CETP-LDLR and SR-BI, while in mice and rats, cholesterol is transported to liver via SR-BI expressed in liver. Overexpression of SR-BI in mice induces a decrease in plasma lipids and an increase in the fractional catabolic rate for HDL (Wang, 1998). In contrast, SR-BI-KO mice show increases in plasma cholesterol levels, HDL particle size, and levels of apoE and apoA-I in HDL particles (Rigotti, 1997). These results demonstrate the function of SR-BI in reverse cholesterol transport. However, these changes in plasma lipid levels reflect HDL lipid levels, because mice do not have CETP activity in the plasma.

\section{Species differences in phenotypes between genetically modified animals}

Table 2 shows species differences in phenotypes of lipoprotein metabolism between genetically modified animals when the same genes were modified. Overexpression of apoB100 increased HDL-cholesterol but had no effect on non-HDL-cholesterol in mice fed a chow diet (Farese, 1996) but increased in cholesterol levels in plasma and LDL in rabbits (Fan, 1995). Overexpression of apoE decreased levels of apoB-containing lipoproteins in mice (Shimano, 1992) but increased cholesterol levels in plasma and LDL in rabbits (Fan, 1998). In addition, overexpression of PLTP increased HDL-cholesterol and apoA-I levels but did not affect LDL-cholesterol in mice (Jiang, 1996), while it increased LDL-cholesterol and did not affect HDL in rabbits (Masson, 2011). These differences may be due to high CETP activity in rabbits and no CETP activity in mice. Lipoprotein(a) is detected in humans and monkeys, and is an atherogenic lipoprotein. In mice overexpressing human apo(a) (Chiesa, 1992), apo(a) did not bind to mouse LDL particles, while in rabbits, human apo(a) can bound to rabbit LDL particles and formed Lp(a) (Rouy, 1998; Fan, 1999). Finally, LDLR-KO increased cholesterol levels mildly in plasma and LDL in mice (Ishibashi, 1993) and rats (Asahina, 2012), while spontaneous LDLR-deficient rabbits (WHHL or WHHLMI rabbits) show severe hypercholesterolemia due to the accumulation of LDL in plasma even on a normal diet (Goldstein, 1993; Shiomi, 2003; 2009). In humans, LDLR-deficiency produces severe hypercholesterolemia due to the accumulation of LDL in plasma. These differences in effects of LDLR between humans / rabbits and mice / rats may be due to the expression of apobec-1 in the liver and CETP activity in the plasma. Therefore, one has to consider species differences when using animal models. LDLR-KO mice on a high-fat diet showed dramatic hypercholesterolemia (Ishibashi, 1994), and the plasma cholesterol level is comparable with or higher than that of apoE-KO mice. In contrast, the degree of atherosclerosis is greater in 
apoE-KO mice than LDLR-KO mice. In addition, LDLR-KO mice on a chow diet did not show massive atherosclerotic lesions at the age of 12 months (Ishibashi, 1994), while apoE$\mathrm{KO}$ mice on a chow diet for the same period showed massive atherosclerotic lesions (Zhang, 1992 and Reddick, 1994). These differences in plasma lipid profiles and atherosclerosis are not fully understood but are likely to be attributable to the quality or subtype of the circulating lipoproteins.

\begin{tabular}{|c|c|c|}
\hline Genes modification & Mice and/or rats & Rabbits \\
\hline Apo-B100 overexpression & $\begin{array}{c}\text { Increase in HDL-cholesterol } \\
\text { and no effect on non-HDL- } \\
\text { cholesterol on chow feeding }\end{array}$ & $\begin{array}{c}\text { Increase in plasma and LDL } \\
\text { cholesterol }\end{array}$ \\
\hline Apo-E overexpression & $\begin{array}{c}\text { Decrease in non-HDL } \\
\text { cholesterol }\end{array}$ & $\begin{array}{c}\text { Increase in plasma and LDL } \\
\text { cholesterol }\end{array}$ \\
\hline Apo (a) overexpression & Not bind to mouse LDL & $\begin{array}{c}\text { Binds to rabbit LDL and } \\
\text { forms Lp(a) }\end{array}$ \\
\hline PLTP overexpression & $\begin{array}{c}\text { Increase in HDL-cholesterol } \\
\text { and apoA-I but no effects on } \\
\text { LDL-cholesterol }\end{array}$ & $\begin{array}{c}\text { Increase in LDL-cholesterol } \\
\text { but no effect on HDL }\end{array}$ \\
\hline LDLR-deficiency & $\begin{array}{c}\text { Mild increase in plasma } \\
\text { cholesterol }\end{array}$ & $\begin{array}{c}\text { Marked increase in plasma } \\
\text { cholesterol }\end{array}$ \\
\hline
\end{tabular}

Table 2. Species differences in phenotype on overexpression of the same genes.

\section{Genetically modified animal models for human dyslipidemia}

Table 3 summarizes plasma lipid profiles of genetically modified animal models for human dyslipidemia. Plasma lipid and/or lipoprotein profiles of genetically modified mice resemble those for human diseases involving apoC-II deficiency, LPL deficiency, and CETP deficiency. However, plasma lipid levels and lipoprotein profiles of genetically deficient mice are markedly different from those of humans with a deficiency of ABCA1, apoE or LDLR. In ABCA1-KO mice, cholesterol levels markedly decreased in not only HDL but whole plasma, while patients with Tangier disease, who do not have ABCA1 and show very low levels of HDL-cholesterol, exhibit a mild decrease in plasma cholesterol levels. This difference between ABCA1-KO mice and patients with Tangier disease may be due to CETP activity in plasma. ApoE-KO mice fed normal chow show hypercholesterolemia and the increased lipoprotein fraction is VLDL, which contains apoB-48, although plasma triglyceride levels are almost normal. In addition, HDL-cholesterol levels are markedly low. However, patients with apoE deficiency show type III hyperlipidemia by the WHO classification. The increased lipoprotein is VLDL and IDL, and both cholesterol and triglyceride levels are increased. HDL cholesterol is almost normal (Mabuchi, 1989). These differences in lipoprotein metabolism between mice and patients may be due to the expression of apobec- 1 in mouse liver and the triglyceride content of the VLDL fraction. Considering these observations, the hypercholesterolemia in apoE-KO mice may not reflect human hypercholesterolemia. In LDLR deficiency, although humans and rabbit models show marked hypercholesterolemia 
due to the accumulation of LDL in plasma despite a normal diet (Watanabe, 1980; Shiomi, 2009), the accumulation of LDL in plasma in homozygous LDLR-KO mice is mild (Ishibashi, 1993; 1994). These differences in plasma lipid levels and lipoprotein profiles between LDLRKO mice and familial hypercholesterolemia or WHHL rabbits are due to the rapid clearance of apoB-48-containing VLDL, IDL, and LDL through apoER in mouse liver. Recently, LDLRKO rats were developed (Asahina, 2012) . These animals have a similar lipoprotein profile to LDLR-KO mice. Studies demonstrate that both the expression of apobec-1 in liver and a deficiency of CETP in plasma greatly affect lipoprotein metabolism and plasma lipid levels in mice and rats. To solve these problems with LDLR-KO mice and apoE-KO mice, cross breeding with apobec-1-KO/CETP-expressing animals may be required in studies of lipoprotein metabolism. In the development of statins, potent anti-hyperlipidemic agents used by more than 40 million patients world-wide, no cholesterol-lowering effect was observed in mice and rats, although strong cholesterol-lowering effects were found in rabbits, dogs, monkeys and chickens (Tsujita, 1986). In addition, simvastatin, a statin, did not decrease serum cholesterol levels in LDLR-KO mice and CETP(+/-)LDLR(-/-)mice, and increased serum cholesterol levels in apoE-KO mice at a dose of $30 \mathrm{mg} / \mathrm{kg} / \mathrm{day}$ (Yin, 2012), although an extremely high dose of statins $(0.168 \%$ in diet, $200-300 \mathrm{mg} / \mathrm{kg} /$ day) decreased serum cholesterol levels in LDLR-KO mice (Krause, 1998). In contrast, WHHL rabbits, an animal model of familial hypercholesterolemia, have played important roles in studies of the hypocholesterolemic effects and anti-atherosclerotic effects of statins (Shiomi, 1995; 2009). The cholesterol-lowering effect of statins is mainly mediated by an increase in LDLR in liver. Therefore, the effect is weak when the contribution of LDLR to the regulation of plasma cholesterol levels is small, as in mice and rats. These studies suggest the need to select animal models based on study purposes.

\begin{tabular}{|c|c|c|}
\hline Gene modification & Mice and/or rats & Human \\
\hline ABCA1 deficiency & $\begin{array}{l}\text { Marked decrease in cholesterol } \\
\text { levels in both plasma and HDL }\end{array}$ & $\begin{array}{c}\text { Tangier disease, } \\
\text { Marked decrease in HDL } \\
\text { cholesterol but mild decrease in } \\
\text { plasma cholesterol }\end{array}$ \\
\hline apoC-II deficiency & Hypertriglyceridemia & Hypertriglyceridemia \\
\hline apoE-deficiency & $\begin{array}{c}\text { Hypercholesterolemia } \\
\text { Increase in VLDL and decrease in } \\
\text { HDL }\end{array}$ & $\begin{array}{c}\text { Combined hyperlipidemia } \\
\text { Increase in IDL and no changes } \\
\text { in HDL }\end{array}$ \\
\hline LDLR-deficiency & $\begin{array}{l}\text { Mild increase in plasma cholesterol } \\
\text { Mild increase in LDL }\end{array}$ & $\begin{array}{l}\text { Hypercholesterolemia } \\
\text { Marked increase in LDL }\end{array}$ \\
\hline LPL deficiency & $\begin{array}{c}\text { Hypertriglyceridemia } \\
\text { Lethal right after birth in } \\
\text { homozygotes }\end{array}$ & Hypertriglyceridemia \\
\hline CETP deficiency & $\begin{array}{l}\text { High HDL cholesterol (wild-type } \\
\text { mice) }\end{array}$ & High HDL cholesterol \\
\hline
\end{tabular}

Table 3. Plasma lipid profiles of genetically modified animal models for human dyslipidemia 


\section{Conclusion}

In this chapter, the authors summarized achievements of studies using genetically modified animal models in lipoprotein research. The cross-breeding of genetically modified animals, such as double $\mathrm{KO}$ mice, triple $\mathrm{KO}$ mice, and others, has contributed to studies of lipoprotein metabolism. Studies using genetically modified mice have elucidated the mechanisms of cholesterol absorption in the intestine, lipolysis of apoB-containing lipoproteins, lipoprotein receptor function, and cholesterol efflux from macrophages to HDL. Although genetically modified animals are useful to elucidate the function of genes related to lipoprotein metabolism, we have to carefully select animal species to know the effect of these genes on lipid levels of whole plasma and lipoprotein profiles in humans. In addition, genetically modified mice have limitations in studies about the development of hypocholesterolemic agents, because of the expression of apobec-1 in liver and a deficiency of CETP activity in plasma. Consequently, these fundamental differences in lipoprotein metabolism between mice and humans affect the interpretation of results of gene modification about lipoprotein metabolism in mice. To solve these problems, genetically modified mice should be produced using CETP-transgenic/apobec-1-KO mice or animals having a background of no expression of apobec- 1 in the liver and expression of CETP in plasma. We have to be careful in the interpretation of results obtained using genetically modified animals, and to select animal models in response to study purposes to extrapolate the results to humans. Recently, techniques of X-linked severe combined immunodeficiency (X-SCID) using zinc-finger nucleases, transcriptional activator-like effector nucleases (TALEN), and mutation using an N-ethyl-N-nitrosourea mutagenesis have become available for knockout gene expression. These techniques will be able to produce $\mathrm{KO}$-animals other than mice. These animals will contribute further to studies of lipoprotein metabolism and lipid disorders in humans.

\section{Author details}

Masashi Shiomi, Tomonari Koike and Tatsuro Ishida

Kobe University Graduate School of Medicine, Japan

\section{Acknowledgement}

This work was supported in part by grants-in-aid for scientific research from the Ministry of Education, Culture, Sports and Technology, Japan (23300157).

\section{References}

Aalto-Setala, K. (1992). Transgenic animals in lipoprotein research. Ann Med, Vol.24, No.5, pp.405-409

Agellon, L.B.; Walsh, A.; Hayek, T.; Moulin, P.; Jiang, X.C.; Shelanski, S.A.; Breslow, J.L. \& Tall, A.R. (1991). Reduced high density lipoprotein cholesterol in human cholesteryl ester transfer protein transgenic mice. J Biol Chem, Vol.266, No.17, pp.10796-10801 
Allan, C.M. \& Taylor, J.M. (1996). Expression of a novel human apolipoprotein (apoC-IV) causes hypertriglyceridemia in transgenic mice. J Lipid Res, Vol 37, No. 7, pp. 1510-1518

Altmann, S.W.; Davis, H.R.; Yao, X.; Laverty, M.; Compton, D.S.; Zhu, L.J.; Crona, J.H.; Caplen, M.A.; Hoos, L.M.; Tetzloff, G.; Priestley, T.; Burnett, D.A.; Strader, C.D. \& Graziano, M.P. (2002). The identification of intestinal scavenger receptor class B, type I (SR-BI) by expression cloning and its role in cholesterol absorption. Biochim Biophys Acta, Vol.1580, No.1, pp. 77-93

Altmann, S. W.; Davis, H. R.; Zhu, L.; Yao, X.; Hoos, L. M.; Tetzloff, G.; Iyer S. N.; Maguire, M.; Golovko, A.; Zeng, M.; Wang, L.; Murgolo, N. \& Graziano, M. P. (2004). NiemannPick C1 like 1 protein is critical for intestinal cholesterol absorption. Science, Vol.303, No.5661, pp.1201-1204

Asahina, M.; Mashimo, T.; Takeyama, M.; Tozawa, R.; Hashimoto, T.; Takizawa, A.; Ueda, M.; Aoto, T.; Kuramoto, K. \& Serikawa, T. (2012). Hypercholesterolemia and atherosclerosis in low density lipoprotein receptor mutant rats. Biochem Biophys Res Commun, Vol. 418, No.3, pp. 553-558

Berge, K.E.; Tian, H.; Graf, G.A.; Yu, L.; Grishin, N.V.; Schultz, J.: Kwiterovich, P.; Shan, B.; Barnes, R. \&, Hobbs, H.H. (2000). Accumulation of dietary cholesterol in sitosterolemia caused by mutations in adjacent ABC transporters. Science, Vol.290, No.5497, pp.17711775.

Bradley A, Evans M, Kaufman MH, \& Robertson E. (1984). Formation of germ-line chimaeras from embryo-derived teratocarcinoma cell lines. Nature, Vol.309, No.5965, pp. 255-256

Braschi, S., Couture, N.; Gambarotta, A.; Gauthier, B.R.; Coffill, C.R.; Sparks, D.L.; Maeda, N. \& Schultz, J.R. (1998). Hepatic lipase affects both HDL and ApoB-containing lipoprotein levels in the mouse. Biochim Biophys Acta, Vol.1392, No.2-3, pp.276-290

Broedl, U.C; Maugeais, C.; Marchadier, D.; Glick, J.M. \& Rader, D.L. (2003). Effects of nonlipolytic ligand function of endothelial lipase on high density lipoprotein metabolism in vivo. J Biol Chem, Vol.278, No.42, pp.40688-40693

Buhman, K.K.; Accad, M.; Novak, S; Choi, R.S.; Wong, J.S.; Hamilton, R.L.; Turley, S. \&, Farese, R.V. Jr. (2000). Resistance to diet-induced hypercholesterolemia and gallstone formation in ACAT2-deficient mice. Nat Med, Vol.6, No.12, pp.1341-1347

Chapman, M.J. (1980). Animal lipoproteins: Chemistry, structure, and comparative aspects. J Lipid Res. Vol.21, No., pp.789-853

Chiesa, G.; Hobbs, H.H.; Koschinsky, M.L.; Lawn R.M.; Maika, S.D. \& Hammer, R.E. (1992). Reconstitution of lipoprotein(a) by infusion of human low density lipoprotein into transgenic mice expressing human apolipoprotein(a). J Biol Chem, Vol.267, No.34, pp. 24369-24374

Christoffersen, C.; Ahnström, J.; Axler, O.; Christensen, E.I.; Dahlbäck, B. \& Nielsen, L.B. (2008). The signal peptide anchors apolipoprotein $M$ in plasma lipoproteins and prevents rapid clearance of apolipoprotein M from plasma. J Biol Chem, Vol.283, No.27, pp.18765-18772

Christoffersen, C,; Jauhiainen, M.; Moser, M.; Porse, B.; Ehnholm, C.; Boesl, M.; Dahlbäck, B. \& Nielsen, L.B. (2008). Effect of apolipoprotein $M$ on high density lipoprotein 
metabolism and atherosclerosis in low density lipoprotein receptor knock-out mice. $J$ Biol Chem, Vol.283, No.4, pp.1839-1847

Coleman, T.; Seip, R.L.; Gimble, J.M.; Kee, D.; Meda, N. \& Semenkovich, C.F. (1995). COOHterminal disruption of lipoprotein lipase in mice is lethal in homozygotes, but heterozygotes have, elevated triglycerides and impaired enzyme activity. J Biol Chem, Vol.270, No. 21, pp. 12518-12525

Davis, H.R. Jr.; Zhu, L.J.; Hoos, L.M.; Tetzloff, G.; Maguire, M.; Liu, J.; Yao, X.; Iyer, S.P.N.; Lam, M.H.; Lund, E.G.; Detmers, P.A.; Graziano, M.P. \& Altman, S.W. (2004). NiemannPick C1 like 1 (NPC1L1) is the intestinal phytosterol and cholesterol transporter and a key modulator of whole-body cholesterol homeostasis. J Biol Chem, Vol. 279, No.32, pp. 33586-33592

Ding, Y.; Wang, Y.; Zhu, H.; Fan, J.; Liu, G. \& Liu. E. (2011). Hypertriglyceridemia and delayed clearance if fat load in transgenic rabbits expressing human apolipoprotein CIII. Transgenic Res, Vol 20, No.4, pp.867-875

Duverger, N.; Kruth, H.; Emmanuel, F.; Caillaud, J.M.; Viglietta, C.; Castro, G.; Tailleux, A.; Fievet, C.; Fruchart, J.C.; Houdebine, L.M. \& Denefle, P. (1996). Inhibition of atherosclerosis development in cholesterol-fed human apolipoprotein A-I-transgenic rabbits. Circulation. Vol.94, No.4, pp.713-717

Elsøe, S.; Ahnström, J.; Christoffersen, C.; Hoofnagle, A.N.; Plomgaard, P.; Heinecke, J.W.; Binder, C.J.; Björkbacka, H.; Dahlbäck, B. \& Nielsen, L.B. (20129. Apolipoprotein M binds oxidized phospholipids and increases the antioxidant effect of HDL. Atherosclerosis, Vol.221, No.1, pp.91-97

Fan, J.; Araki, M.; Wu, L.; Challah, M.; Shimoyamada, H.; Lawn, R.M.; Kakuta, H.; Shikama, H. \& Watanabe, T. (1999). Assembly of lipoprotein (a) in transgenic rabbits expressing human apolipoprotein (a). Biochem Biophys Res Commun, Vol.255, No.3, pp.639-644.

Fan, J.; Ji, Z.S.; Huang, Y.; de Silva, H.; Sanan, D.; Mahley, R.W.; Innerarity, T.L. \& Taylor, J.M. (1998). Increased expression of apolipoprotein $\mathrm{E}$ in transgenic rabbits results in reduced levels of very low density lipoproteins and an accumulation of low density lipoproteins in plasma. J Clin Invest, Vol.101, No.10, pp.2151-2164

Fan, J.; McCormick, S.P.; Krauss, R.M.; Taylor, S.; Quan, R.; Taylor, J.M. \& Young, S.G. (1995). Overexpression of human apolipoprotein B-100 in transgenic rabbits results in increased levels of LDL and decreased levels of HDL. Arteroscler Thromb Vasc Biol, Vol.15, No.11, pp.1889-1899

Fan, J.; Unoki, H.; Kojima, N.; Sun, H.; Shimoyamada, H.; Deng, H.; Okazaki, M.; Shikama, H.; Yamada, N. \& Watanabe, T. (2001). Overexpression of lipoprotein lipase in transgenic rabbits inhibits diet-induced hypercholesterolemia and atherosclerosis. J Biol Chem, Vol.276, No.43, pp.40071-40079

Fan, J., Wang. J. Bensadoun, A., Lauer, S.J., Dang, Q., Mahley, R.W. \& Taylor, J.M. (1994). Overexpression of hepatic lipase in transgenic rabbits leads to a marked reduction of plasma high density lipoprotein and intermediate density lipoproteins. Proc Natl Acd Sci USA,Vol. 91, No. 18, pp. 8724-8728

Fan, J. \& Watanabe, T. (2003). Transgenic rabbits as therapeutic protein bioreactors and human disease models. Pharmacology and Therapeutics, Vol.99, No.3, pp. 261-282 
Farese, R.V.Jr.; Cases, S.; Ruland, S.L.; Kayden, H.J.; Wong, J.S.; Young, S.G. \& Hamilton, R.L. (1996). A novel function for apolipoprotein B: lipoprotein synthesis in the yolk sac is critical for maternal-fetal lipid transport in mice. J Lipid Res, Vol.37, No.2, pp.347-360

Farese, R.V.Jr.; Ruland, S.L.; Flynn, L.M.; Stokowski, R.P. \& Young, S.G. (1995). Knockout of the mouse apolipoprotein $B$ gene results in embryonic lethality in homozygotes and protection against diet-induced hypercholesterolemia in heterozygotes. Proc Natl Acad Sci USA, Vol .92, No.5, pp.1774-1778

Frykman, P.K.; Brown, M.S.; Yamamoto, T.; Goldstein, J.L. \& Herz, J. (1995). Normal plasma lipoproteins and fertility in gene-targeted mice homozygous for a disruption in the gene encoding very low density lipoprotein receptor. Proc Natl Acad Sci U S A, Vol.92, Mo.18, pp.8453-8457

Garcia-Calvo, M.; Lisnock, J.; Bull, H.G.; Hawes, B.E.; Burnett, D.A.; Braun, M.P.; Crona, J.H.; Davis, H.R. Jr.; Dean. D.C.; Detmers, P.A.; Graziano, M.P.; Hughes, M.; Macintyre, D.E.; Ogawa, A.; O'neill, K.A.; Iyer, S.P.; Shevell, D.E.; Smith, M.M.; Tang, Y.S.; Makarewicz, A.M.; Ujjainwalla, F.; Altmann, S.W.; Chapman, K.T. \& Thornberry, N.A. (2005). The target of ezetimibe is Niemann-Pick C1 like 1 (NPC1L1). Proc Natl Acd Sci U $S$ A, Vol. 102, No. 23, pp. 8132-8137

Gautier, T.; Masson, D.; Jong, M.C.; Duverneuil, L.; Guern, N.L.; Deckert, V.; de Barros, J.P.; Dumont, L.; Bataille, A.; Zak, Z.; Jiang, X.; Tall, A.R.; Havekes, L.M. \& Lagrost, L. (2002). Apolipoprotein CI deficiency markedly augments plasma lipoprotein changes mediated by human cholesterol ester transfer protein (CETP) in CETP transgenic/apoCI-knocked out mice. J Biol Chem, Vol 277, No.35, pp. 31354-31363

Goldstein, J.L.; Kita, T. \& Brown, M.S. (1983). Defective lipoprotein receptors and atherosclerosis: Lessons from an animal counterpart of familial hypercholesterolemia. $N$ Engl J Med, Vol. 309, No.5, pp. 288-296

Gonzalez-Navarro, H.; Nong, Z.; Amar, M.J.A.; Shamburek, R.D.; Najib-Fruchart, J.; Paigen, B.J.; Brewer, B. Jr. \& Santamarina-Fojo, S. (2004). The ligand-binding function of hepatic lipase modulates the development of atherosclerosis in transgenic mice. J Biol Chem, Vol.279, No.44, pp. 45312-45321

Gordon, J. W. \& Ruddle, F.H. (1982). Germ line transmission in transgenic mice. Progress in Clinical and Biological Research, Vol.85, pp. 111-124.

Greeve, J.; Altkemper, I.; Dieterich, J.H.; Greten, H. \& Windler, E. (1993). Apolipoprotein B mRNA editing in 12 different mammalian species: hepatic expression is reflected in low concentrations of apoB-containing plasma 1ipoproteins. J Lipid Res, Vol.34, No. 8, pp. 1367-1383.

Hammer, R.E., Pursel, V.G., Rexroad, C.E. Jr., Wall, R.J., Bolt, D.J., Ebert, K.M., Palmiter, R.D. \& Brinster, R.L. (1985). Production of transgenic rabbits, sheep and pigs by microinjection. Nature, Vol.315, No.6021, pp. 680-683

Hayek, T.; Oiknine, J.; Brook, J.G. \& Aviram, M. (1994). Role of HDL apolipoprotein E in cellular cholesterol efflux: studies in apo E knockout transgenic mice. Biochem Biophys Res Commun, Vol.205, No.2, pp.1072-11078

Herbert B, Patel D, Waddington SN, Eden ER, McAleenan A, Sun XM, Soutar AK. (2010). Increased secretion of lipoproteins in transgenic mice expressing human D374Y PCSK9 
under physiological genetic control. Arterioscler Thromb Vasc Biol,Vol.30, No.7, pp.13331339

Herrera, V.L.; Makrides, S.C.; Xie, H.X.; Adari, H.; Krauss, R.M.; Ryan, U.S. \& Ruiz-Opazo, N. (1999). Spontaneous combined hyperlipidemia, coronary heart disease and decreased survival in Dahl salt-sensitive hypertensive rats transgenic for human cholesteryl ester transfer protein. Nat Med, Vol.5, No.12, pp.1383-1389

Hoeg, J.M.; Santamarina-Fojo, S.; Bérard, A.M.; Cornhill, J.F.; Herderick, E.E.; Feldman, S.H.; Haudenschild, C.C.; Vaisman, B.L.; Hoyt, R.F.Jr.; Demosky, S.J.Jr.; Kauffman, R.D.; Hazel, C.M.; Marcovina, S.M. \& Brewer, H.B. Jr. (1996). Overexpression of lecithin:cholesterol acyltransferase in transgenic rabbits prevents diet-induced atherosclerosis. Proc Natl Acad Sci U S A, Vol.93, No.21, pp.11448-11453

Hoeg, J. M.; Vaisman, B. L.; Demosky, S.J. Jr.; Meyn, S.M.; Talley, G.D.; Hoyt, R.F. Jr.; Feldman, S.; Berard, A.M.; Sakai, N.; Wood, D.; Brousseau, M.E.; Marcovina, S.; Brewer, H.B.Jr. \& Santamarina-Hojo, S. (1996). "Lecithin:cholesterol acyltransferase overexpression generates hyperalpha-lipoproteinemia and a nonatherogenic lipoprotein pattern in transgenic rabbits. J Biol Chem, Vol.271, No.8, pp. 4396-4402

Hofmann, S.L.; Russell, D.W.; Brown, M.S.; Goldstein, J.L. \& Hammer, R.E. (1988). Overexpression of low density lipoprotein (LDL) receptor eliminates LDL from plasma in transgenic mice. Science, Vol.239, No.4845, pp.1277-1281

Huang, Z.H.; Minshall, R.D. \& Mazzone, T. (2009). Mechanism for endogenously expressed apoE modulation of adipocyte very low density lipoprotein metabolism. J Biol Chem, Vol.284, No.46, pp.31512-13522

Huijgen, R.; Fouchier, S.W.; Denoun, M.; Hutten, B.A.; Vissers, M.N.; Lambert, G. \& Kastelein, J.J.P. (2012). Plasma levels of proprotein convertase subtilisin Kexin type 9 (PCSK9) and phenotypic variability in familial hypercholesterolemia. J Lipid Res, (in press)

Hussain, M.M.; Rava, P.; Walsh, M.; Rana, M. \& Iqbal, J. (2012). Multiple functions of microsmal triglyceride transfer protein. Nutr Metab, Vol. 9, No. , pp. 14-

Ishibashi, S.; Brown, M.S.; Goldstein, J.L.; Gerard, R.D.; Hammer, R.E. \& Herz, J. (1993). Hypercholesterolemia in low density lipoprotein receptor knockout mice and its reversal by adenovirus-mediated gene delivery. J Clin Invest, Vol.92, No.2, pp.883-893

Ishibashi, S., Goldstein, J.L., Brown, M.S., Herz, J. \& Burns, D.K. (1994). Massive xanthomatosis and atherosclerosis in cholesterol-fed low density lipoprotein receptornegative mice. J Clin Invest, Vol.93, No.5, pp.1885-1893

Ishida, T.; Choi, S.; Kundu, R.K.; Hirata, K.; Rubin, E.M.; Cooper ,A.D. \& Quertermous, T. (2003). Endothelial lipase is a major determinant of HDL level. J Clin Invest, Vol.111, No.3, pp.347-355.

Ishida T, Choi SY, Kundu RK, Spin J, Yamashita T, Hirata K, Kojima Y, Yokoyama M, Cooper AD, Quertermous T. (2004). Endothelial lipase modulates susceptibility to atherosclerosis in apolipoprotein-E-deficient mice. J Biol Chem. Vol.279, No.43, pp45085-92. 
Jiang, X.C.; Bruce, C.; Mar, J.; Lin, M.; Ji, Y.; Francone, O.L; \& Tall, A.R. (1999). Targeted mutation of plasma phospholipid transfer protein gene markedly reduces high-density lipoprotein levels. J Clin Invest, Vol.103, No.6, pp.907-914

Jiang, X.; Francone, O.L.; Bruce, C.; Milne, R.; Mar, J.; Walsh, A.; Breslow, J.L. \& Tall, A.R. (1996). Increased prebeta-high density lipoprotein, apolipoprotein AI, and phospholipid in mice expressing the human phospholipid transfer protein and human apolipoprotein AI transgenes. J Clin Invest, Vol.98, No.10, pp.2373-2380

Jiang, X.C.; Qin, S.; Qiao, C.; Kawano, K.; Lin, M.; Skold, A.; Xiao, X. \& Tall, A.R. (2001). Apolipoprotein B secretion and atherosclerosis are decreased in mice with phospholipid-transfer protein deficiency. Nat Med, Vol.7, No.7, pp.847-852

Kennedy, M.A.; Barrera, G.C.; Nakamura, K.; Baldán, A.; Tarr, P.; Fishbein, M.C.; Frank, J.; Francone, O.L. \& Edwards, P.A. (2005). ABCG1 has a critical role in mediating cholesterol efflux to HDL and preventing cellular lipid accumulation. Cell Metab, Vol.1, No.2, pp.121-131

Kendrick, J.S.; Chan, L. \& Higgins, J.A. (2001). Superior role of apolipoprotein B48 over apolipoprotein B100 in chylomicron assembly and fat absorption: an investigation of apobec-1 knock-out and wild-type mice. Biochem J, Vol.356, No.3, pp. 821-827

Ko KW, Paul A, Ma K, Li L, Chan L. (2005). Endothelial lipase modulates HDL but has no effect on atherosclerosis development in apoE-/- and LDLR-/- mice. J Lipid Res. Vol.46, No.12. pp2586-94.

Koike, T.; Kitajima, S.; Yu, Y.; Li, Y.; Nishijima, K.; Liu, E.; Sun, H.; Wagar, A.B.; Shibata, N.; Inoue, T.; Wang, Y.; Zhang, B.; Kobayashi, J.; Morimoto, M.; Saku, K.; Watanabe, T. \& Fan, J. (2009). Expression of human apoAII in transgenic rabbits leads to dyslipidemia: a new model for combined hyperlipidemia. Arterioscler Thromb Vasc Biology, Vol.29, No.12, pp. 2047-2053.

Koo, C.; Innerarity, T.L. \& Mahley, R.W. (1985). Obligatory role of cholesterol and apolipoprotein $\mathrm{E}$ in the formation of large cholesterol-enriched and receptor-active high density lipoproteins. J Biol Chem, Vol.260, No.22, pp. 11934-11943

Krause, B.R. \& Princen, H.M.G. (1998). Lack of predictablity of classical animal models for hypolipidemic activity: a ggod time for mice? Atherosclerosis, Vol 140, No.1, pp.15-24

Li, X.; Catalina, F.; Grundy, S.M. \& Patel, S. (1996). Method to measure apolipoprotein B-48 and B-100 secretion rates in an individual mouse: evidence for a very rapid turnover of VLDL and preferential removal of B-48- relative to B-100-containing lipoproteins. J. Lipid Res. Vol. 37, No.1, pp. 210-220.

Liu, R.; Iqbal, J.; Yeang, C.; Wang, D.Q.; Hussain, M.M. \& Jiang, X.C. (2007). Phospholipid transfer protein-deficient protein-deficient mice absorb less cholesterol. Arterioscler Thromb Vasc Biol, Vol. 27, No.9, pp. 2014-2021

Liu, Y.; Millar, J.S.; Cronley, D.A,; Graham, M.; Crooke, R, Bilheimer, JT. \& Rader, D.J. (2008). Knockout of acyl-Coa:diacylglycerol acyltransferase 2 with antisense oligonucleotide reduces VLDL TG and apoB secretion in mice. Biochim Biophys Acta, Vol.1781, No. 3, pp.97-104

Lo, C.M.; Nordskog, B.K.; Nauli, A.M.; Zheng, S.; Vonlehmden, S.B.; Yang, Q.; Lee, D.; Swift, L.L.; Davidson, N.O. \& Tso, P. (2008). Why does the gut choose apolipoprotein B48 but 
not B100 for chylomicron formation? Am J Physiol Gastrointest Liver Physio, Vol.294, No.1, pp.G344-G352.

Ma K, Cilingiroglu M, Otvos JD, Ballantyne CM, Marian AJ, Chan L. (2003). Endothelial lipase is a major genetic determinant for high-density lipoprotein concentration, structure, and metabolism. Proc Natl Acad Sci U S A. Vol.100, No.2, pp2748-53.

Mabuchi, H.; Itoh, H.; Takeda, M.; Kajinami, K.; Wakasugi, T.; Koizumi, J.; Takeda, R. \& Asagami, C. (1989). A young type III hyperlipoproteinemic patient associated with apolipoprotein E deficiency. Metabolism, Vol.38, No.2, pp.115-119.

Mardones, P.; Quiñones, V.; Amigo, L.; Moreno, M.; Miquel, J.F.; Schwarz, M.; Miettinen, H.E.; Trigatti, B.; Krieger, M.; VanPatten, S.; Cohen, D.E. \& Rigotti, A. (2001). Hepatic cholesterol and bile acid metabolism and intestinal cholesterol absorption in scavenger receptor class B type I-deficient mice. J Lipid Res, Vol.42, No.2, pp.170-180

Marzal-Casacuberta, A.; Blanco-Vaca, F.; Ishida, B.Y.; Julve-Gil, J.; Shen, J.; Calvet-Márquez, S.; González-Sastre, F. \& Chan, L. (1996). Functional lecithin:cholesterol acyltransferase deficiency and high density lipoprotein deficiency in transgenic mice overexpressing human apolipoprotein A-II. J Biol Chem, Vol.271, No.12, pp.6720-6728

Masson, D.; Deckert, V.; Gautier, T.; Klein, A.; Desrumaux, C.; Viglietta, C.; Pais de Barros, J.P.; Le Guern, N.; Grober, J.; Labbé, J.; Ménétrier, F.; Ripoll, P.J.; Leroux-Coyau, M.; Jolivet, G.; Houdebine, \& Lagrost, L. (2011). Worsening of diet-induced atherosclerosis in a new model of transgenic rabbit expressing the human plasma phospholipid transfer protein. Arterioscler Thromb Vasc Biol, Vol.31,No.4, pp.766-774

Matsuura, F.; Wang, N.; Chen, W.; Jiang, X.C. \& Tall, A.R. (2006). HDL from CETP-deficient subjects shows enhanced ability to promote cholesterol efflux from macrophages in an apoE- and ABCG1-dependent pathway. J Clin Invest, Vol.116, No.5, pp.1435-1442

Mbikay M, Sirois F, Mayne J, Wang GS, Chen A, Dewpura T, Prat A, Seidah NG, Chretien M, Scott FW. (2010). PCSK9-deficient mice exhibit impaired glucose tolerance and pancreatic islet abnormalities. FEBS Lett, Vol.584, No.4, pp.701-706

McNeish, J.; Aiello, R.J.; Guyot, D,; Turi, T.; Gabel, C.; Aldinger, C.; Hoppe, K.L.; Roach, M.L.; Royer, L.J.; de Wet, J.; Broccardo, C.; Chimini, G. \& Francone, O.L. (2000). High density lipoprotein deficiency and foam cell accumulation in mice with targeted disruption of ATP-binding cassette transporter-1. Proc Natl Acad Sci U S A, Vol.97, No.8, pp. $4245-4250$

Mezdour, H.R.; Jones, R.; Dengremont, C.; Castro, G. \& Maeda, N. (1997). Hepatic lipase deficiency increases plasma cholesterol but reduces susceptibility to atherosclerosis in apolipoprotein E-deficient mice. J. Biol. Chem., Vol.272, No.21, pp. 1357013575Morrison, J.R.; Paszty, C.; Stevens, M.E.; Hughes, S.D.; Forte, T.; Scott, J. \& Rubin, E.M. (1996). Apolipoprotein B RNA editing enzyme-deficient mice are viable despite alterations in lipoprotein metabolism. Proc Natl Acad Sci USA, Vol. 93, No.14, pp.71547159

Mulligan, J.D.; Flowers, M.T.; Tebon, A.; Bitgood, J.J.; Wellington, C.; Hayden, M.R. \& Attie, A.D. (2003). ABCA1 is essential for efficient basolateral cholesterol efflux during the absorption of dietary cholesterol in chickens. J Biol Chem, Vol.278, No.15, pp.13356-3366 
Newberry, E.P.; Kennedy, S.M.; Xie, Y.; Luo, J. \& Davidson, N.O. (2009). Diet-induced alterations in intestinal and extrahepatic lipid metabolism in liver fatty acid binding protein knockout mice. Mol Cell Biochem, Vol 326, No. 1-2, pp. 79-86

Otera, H.; Ishida, T.; Nishiuma, T.; Kobayashi, K.; Kotani, Y.; Yasuda, T.; Kundu, R.K.; Quertermous, T.; Hirata, K. \& Nishiuma, Y. (2009). Targeting inactivation of endothelial lipase attenuates lung allergic inflammation through raising plasma HDL level and inhibiting eosinophil infiltration. Am J Physiol Lung Cell Mol Physiol, Vol 296, No. 4, pp. L594-602

Out, R.; Hoekstra, M.; Habets, K.; Meurs, I.; de Waard, V.; Hildebrand, R.B.; Wang, Y.; Chimini, G.; Kuiper, J.; Van Berkel, T.J. \& Van Eck, M. (2008). Combined deletion of macrophage ABCA1 and ABCG1 leads to massive lipid accumulation in tissue macrophages and distinct atherosclerosis at relatively low plasma cholesterol levels. Arterioscler Thromb Vasc Biol, Vol.28, No.2, pp.258-264

Piedrahita, J.A.; Zhang, S.H.; Hagaman, J.R.; Oliver, P.M. \& Maeda N. (1992). Generation of mice carrying a mutant apolipoprotein $\mathrm{E}$ gene inactivated by gene targeting in embryonic stem cell. Proc Natl Acd Sci USA, Vol.89, No.10, pp. 4471-4475

Poirier, S.; Mayer, G.; Benjannet, S.; Bergeron, E.; Marcinkiewicz, J.; Nassoury, N.; Mayer, H.; Nimpf, J.; Prat, A. \& Seidah, N.G. (2008). The proprotein convertase PCSK9 induces the degradation of low density lipoprotein receptor (LDLR) and its closest family members VLDLR and ApoER2. J Biol Chem, Vol.283, No.4, pp.2363-2372

Plump, A.S.; Azrolan, N.; Odaka, H.; Wu, L.; Jiang, X.; Tall, A.; Eisenberg, S. \& Breslow, J.L. (1997). ApoA-I knockout mice: characterization of HDL metabolism in homozygotes and identification of a post-RNA mechanism of apoA-I up-regulation in heterozygotes. J Lipid Res, Vol.38, No.5, pp.1033-1047

Raabe, M.; Flynn, L.M.; Zlot, C.H.; Wong, J.S.; Veniant, M.M.; Hamilton, R.L. \& Young, S.G. (1998). Knockout of the abetalipoproteinemia gene in mice: reduced lipoprotein secretion in heterozygotes and embryonic lethality in homozygotes. Proc Natl Acd Sci USA, Vol.95, No.15, pp.8686-8691

Rashid, S.; Curtis, D.E.; Garuti, R.; Anderson, N.N.; Bashmakov, Y. ; Ho, Y.K.; Hammer, R.E.; Moon, Y.A. \& Horton, J.D. (2005). Decreased plasma cholesterol and hypersensitivity to statins in mice lacking Pcsk9. Proc Natl Acad Sci USA, Vol.102, No.15, pp.5374-5379

Reddick RL, Zhang SH, Maeda N. Atherosclerosis in mice lacking apo E. Evaluation of lesional development and progression. Arterioscler Thromb. 1994;14(1):141-7.

Rigotti, A.; Trigatti, B.L.; Penman, M.; Rayburn, H.; Herz, J. \& Krieger, M. (1997). A targeted mutation in the murine gene encoding the high density lipoprotein (HDL) receptor scavenger receptor class B type I reveals its key role in HDL metabolism. Proc Natl Acad Sci U S A, Vol.94, No.23, pp.12610-12615

Rohrer, L.; Ohnsorg, R.M.; Landolt, F.; Rinninger, F. \& von Eckardstein, A. (2009). High0density lipoprotein transport through aortic endothelial cells involves scavenger receptor BI and ATP-binding cassette transporter G1. Cir Res, Vol.104, No.10, pp.11421150

Rouy, D.; Duverger, N.; Lin, S.D.; Emmanuel, F.; Houdebine, L.M.; Denefle, P.; Viglietta, C.; Gong, E.; Rubin, E.M. \& Hughes, S.D. (1998). Apolipoprotein(a) yeast artificial 
chromosome transgenic rabbits. Lipoprotein(a) assembly with human and rabbit apolipoprotein B. J Biol Chem, Vol. 273, No. 2, pp. 1247-1251

Sanan, D.A.; Newland, D.L.; Tao, R.; Marcovina, S.; Wang, J.; Mooser, V.; Hammer, R,E, \& Hobbs, H.H. (1998). Low density lipoprotein receptor-negative mice expressing human apolipoprotein B-100 develop complex atherosclerotic lesions on a chow diet: No accentuation by apolipoprotein(a). Proc Natl Acad Sci USA; Vol.95, No. 8, pp. 4544-4549

Shachter, N.S.; Hayek, T.; Leff, T.; Smith, J.D.; Rosenberg, D.W.; Walsh, A.; Ramakrishnan, R.; Goldberg, I.J.; Ginsberg, H.N. \& Breslow, J.L. (1994). Overexpression of apolipoprotein CII causes hypertriglyceridemia in transgenic mice. J Clin Invest, Vol.93, No.4, pp.1683-1690

Shimada, M.; Ishibashi, S.; Inaba, T.; Yagyu, H.; Harada, K.; Osuga, J.; Ohashi, K.; Yazaki, Y. \& Yamada, N. (1996). Suppression of diet-induced atherosclerosis in low density lipoprotein receptor knockout mice overexpressing lipoprotein lipase. Proc Natl Acad Sci U S A, Vol.93, No.14, pp.7242-7246

Shimada, M.; Shimano, H.; Gotoda, T.; Yamamoto, K.; Kawamura, M.; Inaba, T.; Yazaki, Y. \& Yamada, N. (1993). Overexpression of human lipoprotein lipase in transgenic mice. Resistance to diet-induced hypertriglyceridemia and hypercholesterolemia. J Biol Chem, Vol.268, No.24, pp.17924-17929

Shimano, H.; Yamada, N.; Katsuki, M.; Shimada, M.; Gotoda, T.; Harada, K.; Murase, T.; Fukazawa, C.; Takaku, F. \& Yazaki, Y. (1992). Overexpression of apolipoprotein E in transgenic mice: marked reduction in plasma lipoproteins except high density lipoprotein and resistance against diet-induced hypercholesterolemia. Proc Natl Acad Sci U S A, Vol.89, No.5, pp.1750-1754

Shiomi, M. \& Ito, T. (2001). MTP inhibitor decreases plasma cholesterol levels in LDL receptor-deficient WHHL rabbits by lowering the VLDL secretion. Eur J Pharmacol Vol.431, No.1, pp 127-131

Shiomi, M. \& Ito, T. (2009). The Watanabe heritable hyperlipidemic (WHHL) rabbit, its characteristics and history of development: A tribute to the late Dr. Yoshio Watanabe. Atherosclerosis, Vol.207, No.1, pp. 1-7.

Shiomi, M.; Ito, T.; Tsukada, T.; Yata, T.; Watanabe, Y.; Tsujita, Y.; Fukami, M.; Fukushige, J.; Hosohawa, T. \& Tamura, A. (1995). Reduction of serum cholesterol levels alters lesional composition of atherosclerotic plaques: Effect of pravastatin sodium on atherosclerosis in mature WHHL rabbits. Arterioscler Theromb Vasc Biol, Vol.15, No.11, pp.1938-1944

Shiomi, M.; Ito, T.; Yamada, S.; Kawashima, S. \& Fan, J. (2003). Development of an animal model for spontaneous myocardial infarction (WHHLMI rabbit). Arterioscler Thromb Vasc Biol, Vol.23, No.7, pp. 1239-1244

Simonet, W.S.; Bucay, N.; Pitas, R.E.; Lauer, S.J. \& Taylor, J.M. (1991). Mulyiple tissuespecific elements control the apolipoprotein E-C-I gene locus in transgenic mice. J Biol Chem, Vol.266, No. 14, pp. 8651-8654

Son, Y.S. \& Zilversmit, D.B. (1989). Increased lipid transfer activities in hyperlipidemic rabbit plasma. Arteriosclerosis, Vol. 6, No.3, pp. 345-351

Strauss, J.G.; Frank, S.; Kratky, D.; Hammerle, G.; Hrzenjak, A.; Knipping, G.; von Eckardstein, A.; Kostner, G.M. \& Zechner, R. (2001). Adenovirus-mediated rescueof 
lipoprotein lipase-deficient mice. Lipolysis of triglyceride-rich lipoproteins is essential for high density lipoprotein maturation in mice. J Biol Chem, Vol. 276, No.39, pp.3608336090.

Suzuki, H.; Kurihara, Y.; Takeya, M.; Kamada, N.; Kataoka, M.; Jishage, K.; Ueda, O.; Sakaguchi, H.; Higashi, T.; Suzuki, T.; Takashima, Y.; Kawabe, Y.; Cynshi, O.; Wada, Y.; Honda, M.; Kurihara, H.; Aburatani, H.; Doi, T.; Matsumoto, A.; Azuma, S.; Noda, T.; Toyoda, Y.; Itakura, H.; Yazaki, Y.; Horiuchi, S.; Takahashi, K.; Kruijt, J.K.; van Berkel, T.J.C.; Steinbrecher, U.P.; Ishibashi, S.; Maeda, N.; Gordon, S. \& Kodama, T. (1997). A role for macrophage scavenger receptors in atherosclerosis and susceptibility to infection. Nature, Vol.386, No.6622, pp. 292-296

Swanson, M. E.; Hughes, T. E.; Denny, I.S.; France, D.S.; Paterniti, J.R.Jr.; Tapparelli, C.; Gfeller, P. \& Burki, K. (1992). High level expression of human apolipoprotein A-I in transgenic rats raises total serum high density lipoprotein cholesterol and lowers rat apolipoprotein A-I. Transgenic Res, Vol.1, No.3, pp. 142-147

Takahashi, S.; Ito, T.; Zenimaru, Y.; Suzuki, J.; Miyamori, I.; Takahashi, M.; Ishida, T.; Hirata, K.; Yamamoto, T.; Iwasaki. T.; Hattori, H. \& Shiomi, M. (2011). Species differences of macrophage very low-density-lipoprotein (VLDL) receptor protein expression. Biochem Biophys Res Commun. Vol.407, No.4, pp.656-662

Takahashi, S.; Sakai, J.; Hattori, H.; Zenimaru, Y.; Suzuki, J.; Miyamori, I. \& Yamamoto T. (2004). The very low-density lipoprotein (VLDL) receptor: characterization and function as a peripheral lipoprotein receptor. J Atheroscler Thromb, Vol.11, No.4, pp. 200-208

Teng, B.; Ishida, B.; Forte, T.M.; Blumenthal, S.; Song, L.Z.; Fotto, A.M. Jr, \& Cham, L. (1997). Effective lowering of plasma, LDL, and esterified cholesterol in LDL receptor-knockout mice by adenovirus-mediated gene delivery of apoB mRNA editing enzyme (Apobec1). Arterioscler Thromb Vasc Biol, Vol. 17, No. 5, pp. 889-897

Tsujita, Y.; Kuroda, M.; Shimada, Y.; Tanzawa, K.; Arai, M.; Kaneko, I.; Tanaka, M.; Masuda, H.; Tarumi, C.; Watanabe, Y. \& Fujii, S. (1986). CS-514, a competitive inhibitor of 3hydroxy-3-methylglutaryl coenzyme A reductase: Tissue-selective inhibition of sterol synthesis and hypolipidemic effect on various animal species. Biochim Biophys Acta, Vol.877, No.1, pp.50-60

Vaisman, B.L.; Klein, H.G.; Rouis, M.; Bérard, A.M.; Kindt, M.R.; Talley, G.D.; Meyn, S.M.; Hoyt, R.F.Jr.; Marcovina, S.M. ; Albers, J.J.; Hoeg, J.M.; Brewer, H.B.Jr. \& SantamarinFojo, S. (1995). Overexpression of human lecithin cholesterol acyltransferase leads to hyperalphalipoproteinemia in transgenic mice. J Biol Chem, Vol.270, No.20, pp.1226912275

Vaisman, B.L.; Lambert, G.; Amar, M.; Joyce, C.; Ito, T.; Shamburek, R.D.; Cain, W.J.; Fruchart-Najib, J.; Neufeld, E.B.; Remaley, A.T.; Brewer, H.B.J. \& Santamarina-Fojo, S. (2001). ABCA1 overexpression leads to hyperalphalipoproteinemia and increased biliary cholesterol excretion in transgenic mice. J Clin Invest. Vol.108, No.2, pp.303-309

Walsh, A.; Ito, Y. \& Breslow, J.L. (1989). High levels of human apolipoprotein A-I in transgenic mice result in increased plasma levels of small high density lipoprotein (HDL) particles comparable to human HDL3. J Biol Chem, Vol. 264, No.11, pp.64886494 
Wang, N.; Arai, T.; Ji, Y.; Rinninger, F. \& Tall. A.R. (1998). Liver-specific overexpression of scavenger receptor BI decreases levels of very low density lipoprotein ApoB, low density lipoprotein $\mathrm{ApoB}$, and high density lipoprotein in transgenic mice. J Biol Chem, Vol.273, No.49, pp.32920-3296

Wang, Y.; Iordanov, H.; Swietlicki, E.A.; Wang, L.; Fritsch, C.; Coleman, T.; Semenkovich, C.F.; Levin, M.S. \& Rubin, D.C. (2005). Targeted intestinal overexpression of the immediate early gene tis7 in transgenic mice increases triglyceride absorption and adiposity. J Biol Chem, Vol. 280, No. 41, pp. 34764-34775

Watanabe, Y. (1980). Serial inbreeding of rabbits with hereditary hyperlipidemia (WHHLrabbit): Incidence and development of atherosclerosis and xanthoma. Atherosclerosis, Vol.36, No.2, pp.261-268

Watanabe, Y.; Ito. T.; Saeki, M.; Kuroda, M.; Tanzawa, K.; Mochizuki M.; Tsujita Y. \& Arai, M. (1981). Hypolipidemic effects of CS-500 (ML-236B) in WHHL-rabbit, a heritable animal model for hyperlipidemia. Atherosclerosis, Vol. 38, No.1-2, pp.27-31

Watanabe, Y.; Ito, T.; Shiomi, M.; Tsujita, Y.; Kuroda, M.; Arai, M.; Fukami, M. \& Tamura, A. (1988). Preventive effect of pravastatin sodium, a potent inhibitor of 3-hydroxy-3methylglutaryl coenzyme A reductase, on coronary atherosclerosis and xanthoma in WHHL rabbits. Biochim Biophys Acta, Vol. 960, No.3, pp.294-302

Weinstock PH, Bisgaier CL, Aalto-Setälä K, Radner H, Ramakrishnan R, Levak-Frank S, Essenburg AD, Zechner R, Breslow JL. (1995). Severe hypertriglyceridemia, reduced high density lipoprotein, and neonatal death in lipoprotein lipase knockout mice. Mild hypertriglyceridemia with impaired very low density lipoprotein clearance in heterozygotes. J Clin Invest. Vol.96, No.6, pp2555-68.

Weng, W. \& Breslow, J.L. (1996). Dramatically decreased high density lipoprotein cholesterol, increased remnant clearance, and insulin hypersensitivity in apolipoprotein A-II knockout mice suggest a complex role for apolipoprotein A-II in atherosclerosis susceptibility. Proc Natl Acad Sci USA, Vol.93, No.25, pp. 14788-14794

Xie, Y.; Newberry, E.P.; Young, S.G.; Robine, S.; Hamilton, R.L.; Wong, J.S.; Luo, J.; Kennedy, S. \& Davidson, N.O. (2006). Compensatory increase in hepatic lipogenesis in mice with conditional intestine-specific Mttp deficiency. J Biol Chem, Vol.281, No.7, pp.4075-86

Yagyu, H.; Lutz, E.P.; Kako, Y.; Marks, S.; Hu, Y.; Choi, S.Y.; Bensadoun, A. \& Goldberg, I.J. (2002). Very low density lipoprotein (VLDL) receptor-deficient mice have reduced lipoprotein lipase activity. Possible causes of hypertriglyceridemia and reduced body mass with VLDL receptor deficiency. J Biol Chem, Vol.277, No.12, pp.10037-10043

Yin, W.; Carballo-Jane, E.; McLaren, D.G.; Mendoza, V.H.; Gagen, K.; Geoghagen, N.S.; McNamara, L.A.; Gorski, J.N.; Eiermann, G.J.; Petrov, A.; Wolf, M.; Tong, X.; Wilsie, L.C.; Akiyama, T.E.; Chen, J.; Thankappan, A.; Xue, J.; Ping, X.; Andrews, G.; Wickham, L.A.; Gai, C.L.; Trinh, T. Kulick, A.A.; Donnelly, M.J.; Voronin, G.O.; Rosa, R.; Cumiskey, A.M.; Bekkari, K.; Mitnaul, L.J.; Puig, O.; Chen, F.; Raubertas, R.; Wong, P.H.; Hansen, B.C.; Koblan, K.S.; Roddy, T.P.; Hubbard, B.K. \& Strack, A.M. (2012). Plasma lipid profiling across species for the identification of optimal animal models of human dyslipidemia. J Lipid Res, Vol 53, No.1, pp. 51-65. 
Young, S. G.; Cham, C.M.; Pittas , R.E.; Burri, B.J.; Connolly, A.; Flynn, L.; Pappu, A.S.; Wong, J.S.; Hamilton, R.L. \& Farese, R.V.Jr. (1995). A genetic model for absent chylomicron formation: mice apolipoprotein B in the liver, but not in the intestine. J Clin Invest, Vol.96, No. 6, pp.2932-2946

Zhang, S.H.; Reddick, R.L.; Piedrahita, J.A. \& Maeda, N. (1992). Spontaneous hypercholesterolemia and arterial lesions in mice lacking apolipoprotein E. Science, Vol.258, No.5081, pp.468-471 